\title{
Synthesis and Elastase Inhibitory Evaluation of Phosphate Esters and Mixed Phosphate Anhydride of Penam Sulfones*
}

\author{
María A. Laborde** and O. A. Mascaretti \\ Instituto de Química Orgánica de Síntesis (IQUIOS-UNR), Casilla de Correo 991,2000Rosario, Argentina \\ E-mail: iquiosra@ citynet.net.ar
}

*This paper missed our publication deadline and was omitted from the Proceedings of the 12th National Symposium of Organic Chemistry (XII SINAQO), published in Molecules 2000, 5, 252-615. The Editorial Board has now decided to publish it separately in this issue.

**Author to whom correspondence should be addressed.

Received: 1 April 2000 / Accepted: 3 April 2000 / Published: 5 April 2000

\begin{abstract}
The evaluation of human leucocite elastase inhibition by phosphate esters (1-2) and phosphate mixed anhydride (3) of penicillin sulfones and their precursor sulfides is described.
\end{abstract}

Keywords: Elastase Inhibition, Phosphate Esters, Phosphate Anhydride, Penam Sulfones.

\section{Introduction}

Human Leukocyte Elastase [1] (HLE, EC 3.4.21.37) is a serine proteinase found in the azurophilic granules of polymorphonuclear leukocytes. This enzyme has been the subject of extensive studies, both in terms of its biological role in numerous diseases [2] and in the development of suitable inhibitors to be used as potential therapeutic agents. This interest has led over the past fifteen years to the synthesis of a wide variety of inhibitors based on the $\beta$-lactam nucleus.

(C) 2000 by MDPI (http://www.mdpi.org). Reproduction is permitted for noncommercial purposes. 


\section{Results and Discussion}

We have recently reported the structure-activity relationship (S.A.R) of several benzyl and methyl 6 - $\alpha$-substituted penicillanate sulfones [3]. In this communication we describe the synthesis and our initial structure-activity relationship study of a series of phosphate triesters (1-2) and phosphatecarboxylate mixed anhydride (3) of penicillin sulfones. These new penicillin derivatives were evaluated as elastase inhibitors using H.L.E.

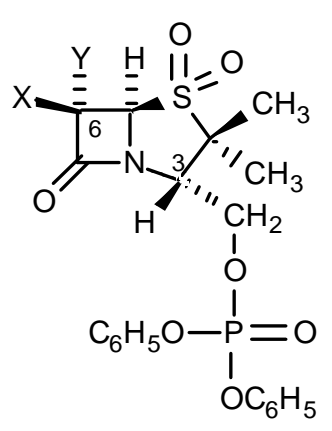

1a $X=Y=B r$

$1 \mathrm{~b} X=\mathrm{H} ; \mathrm{Y}=\mathrm{Cl}$

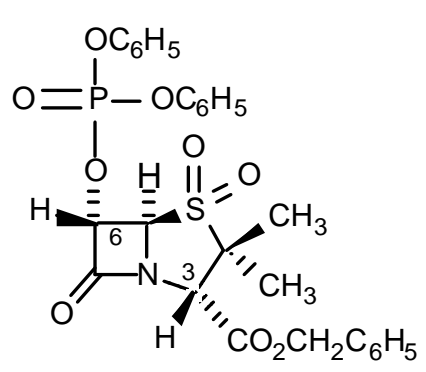

2<smiles>COP(=O)([O-])OC(O)[C@H]1C(C)(C)S(=O)(=O)[C@@]2(Br)N([C@@H](C)O)C(=O)[C@]12Br</smiles>

3

Acknowledgements: UNR, CONICET, Agencia Nacional de Promoción Científica.

\section{References and Notes}

1. a) Edwards, P.D.; Bernstein, P.R. Med. Res. Rev. 1994, 14, 127; b) Hlasta, D.J.; Pagani, E.D. Ann. Rep. Med. Chem. 1994, 29, 195; c) Durette, P.L.; Chabin, R.M. Bioorg. Med. Chem. Lett. 1995, 5, 271.

2. Weinbaum, G.; Giles, R.E.; Krell, R.D. Ann. N.Y. Acad. Sci., 1991, 624, 1-370.

3. Boschetti, C.E.; Mata, E.G.; Mascaretti, O.A.; Cricco, J.A.; Coux, G.; Roveri, O.A. Bioorg. Med. Chem. Lett. 1995, 5, 2033; b) Boschetti, C.E.; Mascaretti, O.A.; Cricco, J.A.; Roveri, O.A. Bioorg. Med. Chem. 1995, 3, 95; c) Boschetti, C.E.; Mata, E.G.; Mascaretti, O.A.; Cricco, J.A.; Coux, G.; Lodeyro, A.; Roveri, O.A. J. Braz. Chem. Soc. 1996, 7, 285.

(C) 2000 by MDPI (http://www.mdpi.org). Reproduction is permitted for noncommercial purposes. 